\title{
ESTUDO GEOMORFOLÓGICO DE BACIAS HIDROGRÁFICAS DO RESERVATÓRIO DO FUNIL, ALTO RIO GRANDE (MG), POR MEIO DE IMAGENS ESTEREOSCÓPICAS ALOS/PRISM
}

\author{
Cassiano Gustavo Messias ${ }^{1}$ \\ Marta Marujo Ferreira ${ }^{2}$
}

\begin{abstract}
Resumo: A disponibilidade atual de produtos de sensoriamento remoto, técnicas de análise espacial e sistemas de informação geográfica, quando utilizados conjuntamente, tem proporcionado bons resultados no mapeamento geomorfológico. Neste sentido, as imagens ALOS/PRISM são uma excelente opção para o estudo do relevo terrestre principalmente em razão da sua alta resolução espacial, combinada a possibilidade de visão estereoscópica. O objetivo deste trabalho foi estudar a geomorfologia de bacias hidrográficas do reservatório do Funil, localizadas na alta bacia do rio Grande, situada no sudeste do estado de Minas Gerais. Pares estereoscópicos gerados a partir de imagens ALOS/PRISM foram utilizados no mapeamento morfodinâmico e de uso do solo destas bacias. Além disso, dados do modelo digital de elevação do sensor ASTER-GDEM, com resolução altimétrica de 30m, foram empregados para produção dos mapas clinográfico, hipsometria e morfologia do relevo. Os resultados mostraram que os produtos de sensoriamento remoto utilizados nessa pesquisa, permitiram mapear com precisão as relações entre processos morfodinâmicos, características físicas das bacias e intervenções humanas no entorno do reservatório.
\end{abstract}

Palavras-chave: geomorfologia; mapeamento morfodinâmico; imagem ALOS/PRISM; reservatório do Funil.

\section{Geomorphological study of Funil reservoir watersheds, upper Grande river basin (MG), using stereoscopic images of ALOS/PRISM sensor}

\begin{abstract}
The current availability of remote sensing products and GIS tools has provided good results when used jointly in geomorphological mapping. In this sense the ALOS/PRISM image is an excellent option to study the earth relief, due its high spatial resolution and stereoscopic view capability. This work aims to study the geomorphology of Funil reservoir watersheds, located on the upper Grande river basin in the southeastern Minas Gerais state. ALOS/PRISM image stereoscopic pairs were tested in the morphodynamic and land use mapping. Slope and relief morphology were mapped using ASTER-GDEM data at $30 \mathrm{~m}$ elevation resolution. The results showed that the remote sensing products used in this research permitted to map the relationship between morphodynamic process, physical characteristics of the watersheds and human interventions around the reservoir.
\end{abstract}

Keywords: geomorphology; morphodynamic mapping; ALOS/PRISM images; reservoir Funil.

\footnotetext{
${ }^{1}$ Doutorando do Programa de Pós-Graduação em Geografia do IG-UNICAMP, Campinas - SP.

${ }^{2}$ Professora Adjunto IV da Universidade Federal de Alfenas - Laboratório de Geomorfologia e Solos - UNIFAL-MG, Alfenas - MG.
} 


\section{INTRODUÇÃO}

A disponibilidade de produtos cartográficos e de teledetecção, aliada ao acesso às tecnologias para análise de informação geográfica, tem permitido avanços e proporcionado maior precisão aos estudos geomorfológicos e ambientais. Segundo Argento (2012) tem-se utilizado os sistemas de informação geográfica (SIG) como suporte operacional ao planejamento ambiental, o que tem possibilitado a geração de cartas, as quais podem ser entrecruzadas a outras informações, atingindo-se um nível de associação multidisciplinar.

A aplicação destes produtos aos estudos geomorfológicos tornou-se fundamental para facilitar a leitura e a representação gráfica dos fatos geomorfológicos. Cunha et. al. (2003) ressaltam que a expressão gráfica das informações geomorfológicas em um único documento cartográfico é tarefa difícil, pois depende da associação entre procedimentos técnicos, objetivos do pesquisador, características da área de estudo e escala de trabalho.

A análise e cartografia do relevo provém da sistematização da hierarquia da paisagem, que propõe a ordenação espacial do relevo e facilita sua identificação (RODRIGUES, 1998). Marujo (1994) enumera alguns estudiosos que estabeleceram critérios para o mapeamento geomorfológico como Klimasweski (1963), Cholley (1950), Demek (1967) e Verstappen e Zuidam (1975). Na definição de escalas para as representações gráficas do relevo, Demeck (1967) propõe a utilização de três níveis hierárquicos à análise geomorfológica: superfícies geneticamente homogêneas, formas de relevo e tipos de relevo. Devido à deficiência ao se representar áreas mais extensas e mais complexas, Ross (1992), propôs uma classificação taxonômica do relevo, em seis níveis, que se estende desde as escalas pequenas, no primeiro táxon, as morfoestruturas, a escalas de detalhe no sexto táxon, os processos geomórficos atuais.

O mapeamento das formas por meio do sexto táxon de Ross (op. cit.) possibilita a análise dos processos de erosão, movimentos de massa e deposição de materiais nas vertentes de forma natural, mas, também, induzidos pela atuação antrópica. Segundo Verstappen (1983, p. 373), os processos nas vertentes compõem maior parte da morfodinâmica estudada em qualquer pesquisa geomorfológica analítica. No entanto, em um estudo de erosão há necessidade de se apresentar detalhes quanto ao tipo, intensidade e padrões de distribuição destes processos.

Com a finalidade de estudar a geomorfologia e cartografar a morfodinâmica em bacias hidrográficas localizadas ao sul da represa formada pela hidrelétrica do Funil - MG, este trabalho utilizou imagens estereoscópicas obtidas pelo sensor Panchromatic Remote-sensing Instrument for 
Stereo Mapping (PRISM), em órbita no satélite Advanced Land Observing Satellite (ALOS). Estas análises são de grande relevância para o planejamento de bacias hidrográficas, pois o mapeamento geomorfológico, elucida problemas geomorfológicos, e, ao mesmo tempo, contribui para evitar a ocorrência dos mesmos, especialmente por meio da identificação de áreas propícias ou não a ocupação humana (BALATKA E SLADEK, 1967).

\section{Geomorfologia, Teledetecção e Utilização de Produtos ALOS/PRISM}

O objeto de estudo da Geomorfologia é a superfície de contato entre a parte sólida, a litosfera, e os meios que a envolvem - líquido e gasoso ou a epiderme da terra (TRICART, 1965). A superfície de contato se constitui no reflexo do equilíbrio dinâmico entre forças antagônicas que reagem de forma natural ou induzida pela ação humana, promovendo mudanças neste equilíbrio.

Os estudos geomorfológicos devem priorizar quatro análises: a morfologia - que se divide em morfografia (avalia os aspectos qualitativos das formas, descrevendo e classificando) e morfometria (avalia os aspectos quantitativos - medição das formas); a morfogênese (investiga a origem das formas) sua evolução ao longo do tempo (a morfocronologia) e a morfodinâmica, que identifica os processos que atuaram no passado ou que ainda atuam no presente, produzindo mudanças na paisagem natural (JOLY, 1977). Entretanto, este autor lembra que, conforme a necessidade do estudo, uma destas análises pode ser focalizada separadamente.

Para Magalhães Jr. e Moreira (1998) mudanças climáticas e/ou eventos tectônicos são responsáveis por rupturas no equilíbrio natural das paisagens. Os autores afirmam que o estudo da morfodinâmica é resultado da relação entre atuação de processos de movimentos de massa e erosão hídrica sobre as vertentes, e, a consequente geração de depósitos coluvionares. Estudos elaborados por Modenesi (1992) no Planalto de Campos do Jordão, apontam que a origem de diversas sequências coluvionares pode ser compatível com ambientes secos e úmidos, com a consequente formação de colúvios detríticos e colúvios de textura fina, respectivamente.

A diversidade e complexidade dos fatos geomorfológicos são estudadas principalmente por meio de métodos e técnicas convencionais, o que inibe a rapidez na identificação, classificação e representação dos elementos do relevo, baseadas na hierarquia taxonômica da paisagem. Por isto, os estudos geomorfológicos devem integrar também técnicas e dados de sensoriamento remoto e geoprocessamento à análise geomorfológica tradicional. 
De acordo com Souza (2006), o desenvolvimento da informática viabiliza interfaces entre sensoriamento remoto em base orbital, a cartografia digital e o SIG. Gustavsson et. al. (2008) afirmam que antes de serem introduzidos os SIG nos estudos geomorfológicos, quando muitos elementos cartografados do relevo fossem combinados, algumas análises de paisagens naturais tornavam-se complexas e lentas. Os autores recomendam que para facilitar a leitura e representação dos elementos do relevo é importante a construção do mapa geomorfológico com o auxílio do SIG, pois o mapa final poderá ser melhor manipulado em meio digital. Para Loureiro e Ferreira (2013), o uso de produtos de sensoriamento remoto, aliado à análise espacial em SIG, permitem avanços na identificação e representação de processos erosivos e movimentos de massa.

Silva (2012) corrobora com os autores citados, afirmando que é possível relacionar geomorfologia e geoprocessamento, especialmente na simulação de processos geomorfológicos ou na criação de modelos. Por outro lado, Souza et. al. (2004) apontam que a utilização do SIG para esta finalidade apresenta deficiências, tais como a carência de símbolos de representação disponíveis nos softwares.

O desenvolvimento de pesquisas ambientais e geomorfológicas foi ressaltado por Nikolakopoulos e Gioti (2010). Para estes pesquisadores o sensor PRISM, do satélite ALOS, que gera imagens pancromáticas com resolução espacial de $2,5 \mathrm{~m}$, é uma importante fonte de dados para a geomorfologia. Diversos estudos já mostraram as possibilidades de utilização de produtos do sensor ALOS/PRISM.

Chaves et. al. (2013) desenvolveram pesquisas no município de Missal - PR, com o propósito de diagnosticar o uso e ocupação do solo, utilizando imagens do sensor ALOS/PRISM. Este estudo mostrou que a resolução espacial e espectral destas imagens permitiu a identificação de treze categorias de uso do solo naquele município. Nikolakopoulos e Gioti (2010) criaram modelos digitais de elevação (MDE) a partir de dados PRISM que mostram boa precisão para o mapeamento geomorfológico de processos erosivos e de movimentos de massa.

Deslizamentos causados pelo terremoto Wenchuan na China, em 2008, foram analisados por Chigira et. al. (2010) por meio do uso e interpretação de imagens dos sensores AVNIR-2 e PRISM. Os autores confirmaram a eficiência destes produtos através dos resultados obtidos, tendo sido mapeados a distribuição, o tamanho e orientação dos eventos ocorridos.

Por outro lado, Castro et. al. (2010) utilizaram imagens ALOS/PRISM para mapear feições erosivas e cicatrizes de deslizamentos no rio Sana, sub-bacia do rio Macaé - RJ. Segundo os autores, a 
ocorrência destes processos está ligada ao tipo de uso e cobertura do solo e às unidades geomorfológicas. O uso de técnicas de geoprocessamento e sensoriamento remoto, aliados à análise geomorfológica, se mostrou muito válido. Neste caso, não foi possível a identificação de todas as feições erosivas utilizando as imagens ALOS/PRISM, mesmo com a alta resolução da imagem, sendo necessários, portanto, trabalhos de campo e utilização de ferramentas de apoio como Google Earth.

É importante ressaltar que estudos geomorfológicos utilizando imagens ALOS/PRISM ainda são escassos e recentes. Contudo, são produtos eficientes que facilitam na compreensão e na interpretação geomorfológica, sobretudo em áreas que carecem de fotografias aéreas em escalas de detalhe. As imagens podem ser adequadas à análise geomorfológica, no que se refere às fases de identificação e mapeamento de compartimentos do relevo e às feições erosivas.

\section{MATERIAL E MÉTODOS}

\section{Área de Estudo}

A hidrelétrica do Funil localiza-se nos municípios de Perdões e Lavras (MG), no Planalto do Alto Rio Grande, bacia do Rio Grande, afluente da bacia do Rio Paraná. A área do estudo deste trabalho compreende as bacias hidrográficas localizadas ao sul desta represa (Figura 1). A importância deste estudo, contextualizado em bacias, deve-se à ativação do processo natural de erosão deflagrado em sistemas naturais que sofrem continuamente a interferência antrópica, culminando no transporte contínuo de materiais de cobertura das vertentes. Neste contexto, o acúmulo de materiais transportados pode comprometer a vida útil da represa do Funil, em razão do assoreamento, e também a qualidade da água do reservatório e de áreas situadas à jusante.

A vegetação no Alto Rio Grande é de maneira geral, formada pela transição entre o cerrado do Brasil Central e florestas semi-decíduas do sul e sudeste do país. São identificados também, campos rupestres e campos de altitude, localizados sobre solos rasos e jovens e em áreas mais elevadas (OLIVEIRA-FILHO et. al., 1994).

No que se refere à geologia, o embasamento é composto por quartzitos, micaxistos, gnaisses graníticos leucocráticos e mesocráticos. Observam-se ainda calcários no município de ljací e sedimentos predominantemente areno-siltosos em áreas próximas ao rio Grande. Em relação à pedologia, nas maiores altitudes associadas a relevos escarpados, predomina o solo Litólico Álico; 
nas médias altitudes o Latossolo Vermelho-Amarelo e, próximo ao leito maior do rio Grande, sedimentos aluvionares (CURI et. al., 1990).

O clima na região onde se insere a área estudada, segundo a classificação de Köppen é do tipo Cwb, com chuvas irregulares distribuídas ao longo do ano, havendo excesso de água nos meses de novembro a março, e deficiência no período de abril a agosto (DANTAS et. al., 2007). Durante os meses de verão o índice pluviométrico anual máximo atinge $2500 \mathrm{~mm}$. No inverno, o índice pluviométrico anual mínimo é de $500 \mathrm{~mm}$, representando uma média anual de $1500 \mathrm{~mm}$. A média anual de temperatura é de $21^{\circ} \mathrm{C}$ com temperatura média no verão de $24^{\circ} \mathrm{C}$ e média no mês mais frio, julho, de $17^{\circ} \mathrm{C}$.

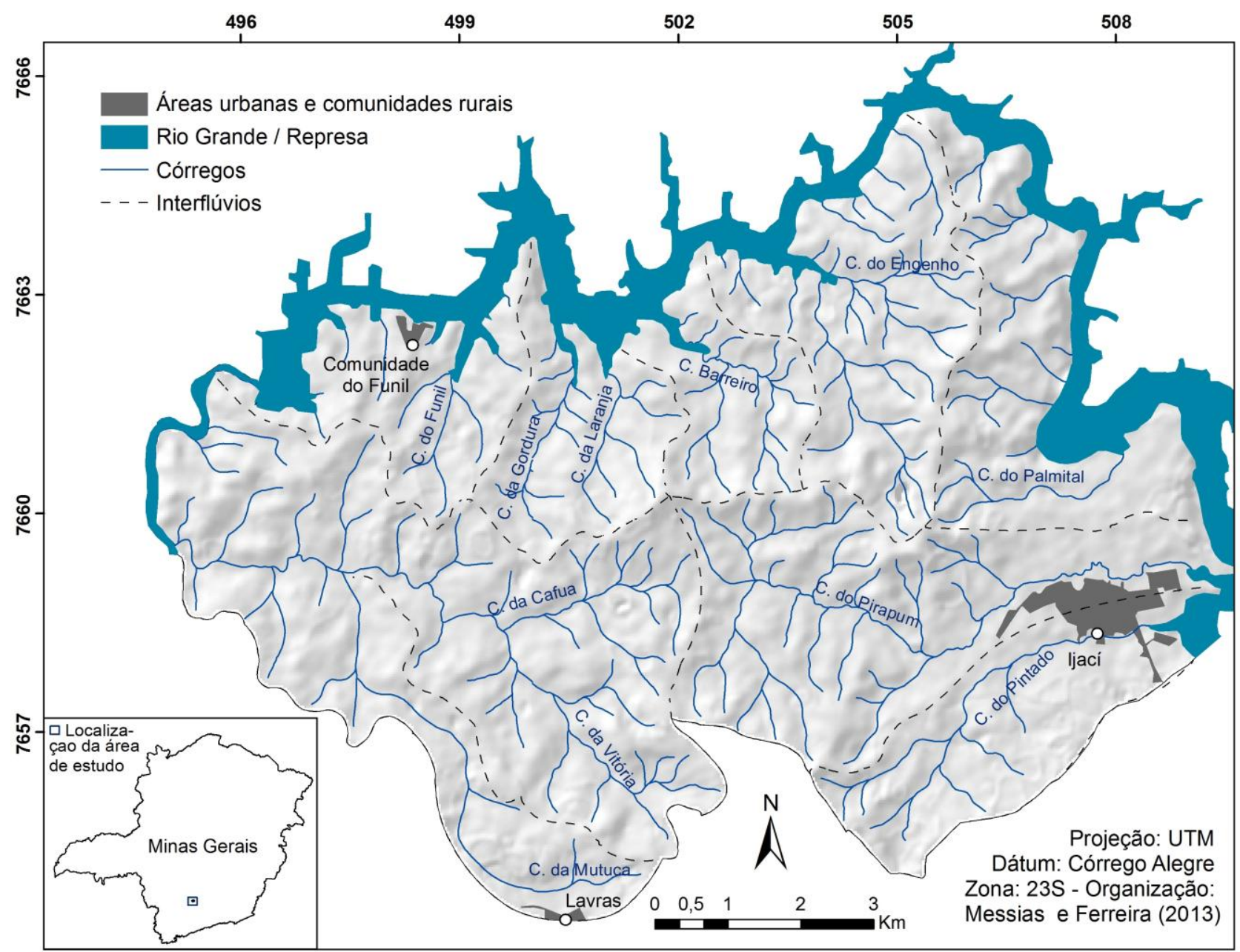

Figura 1 - Mapa de localização e rede hidrográfica da área de estudo 


\section{Material Utilizado}

No desenvolvimento da pesquisa foram utilizados produtos cartográficos e de teledetecção espacial, que serviram de base para a produção dos mapas, obtenção dos resultados e discussão deste trabalho (Tabela 1).

Tabela 1 - Produtos cartográficos e de teledetecção

\begin{tabular}{|c|c|c|c|c|}
\hline Produtos & $\begin{array}{l}\text { Articulação/ } \\
\text { Cena }\end{array}$ & $\begin{array}{c}\text { Escala/ } \\
\text { Resolução }\end{array}$ & Data & Órgão Executor \\
\hline Carta topográfica - Folha Lavras & SF-23-X-Cl-1 & $1: 50.000$ & 1973 & IBGE \\
\hline $\begin{array}{l}\text { Carta topográfica - Folha } \\
\text { Nepomuceno }\end{array}$ & SF-23-I-II-2 & 1:50.000 & 1973 & IBGE \\
\hline $\begin{array}{c}\text { Mapa de solos do estado de Minas } \\
\text { Gerais }\end{array}$ & Folha 4 & $1: 600.000$ & 2010 & $\begin{array}{l}\text { UFV, UFLA, } \\
\text { CETEC,FEAM }\end{array}$ \\
\hline Imagem ALOS/PRISM & $\begin{array}{c}\text { ALPSMN } \\
214644025\end{array}$ & $2,5 \mathrm{~m}$ & $03 / 02 / 10$ & JAXA \\
\hline Dados ASTER/GDEM & S22W045 S22W046 & $30 m$ & 2009 & METI / NASA \\
\hline
\end{tabular}

\section{Criação de Pares Estereoscópicos em Imagens ALOS/PRISM}

Além da alta resolução espacial, o grande diferencial do sensor PRISM, são seus três sistemas ópticos de visualização: Nadir (vertical), Forward (inclinado para a frente) e Backward (inclinado para trás). Forward e Backward possuem inclinação de $+/-23,8$ em relação ao Nadir, o que possibilita a produção de imagens no formato de pares estereoscópicos.

Para serem gerados estes pares, foi utilizado o módulo de pré-processamentos de imagem do software ILWIS 3.4 (ILWIS, 2007). Realizou-se, primeiramente, a correção geométrica, com base em pontos de controle obtidos das cartas topográficas. Além disso, foi realizado contraste, por meio da ferramenta Stretch, expandindo-se o intervalo de níveis de cinza, possibilitando melhor qualidade visual. Na criação de pares estereoscópicos, recortou-se a imagem original de cada sistema óptico em cenas, atribuindo-se mesmas coordenadas e dimensões de 2,5 km no eixo X e 2,0 km no eixo Y. Desta forma, as cenas obtidas por meio de cada sistema correspondem a uma mesma área no espaço (Figura 2). 


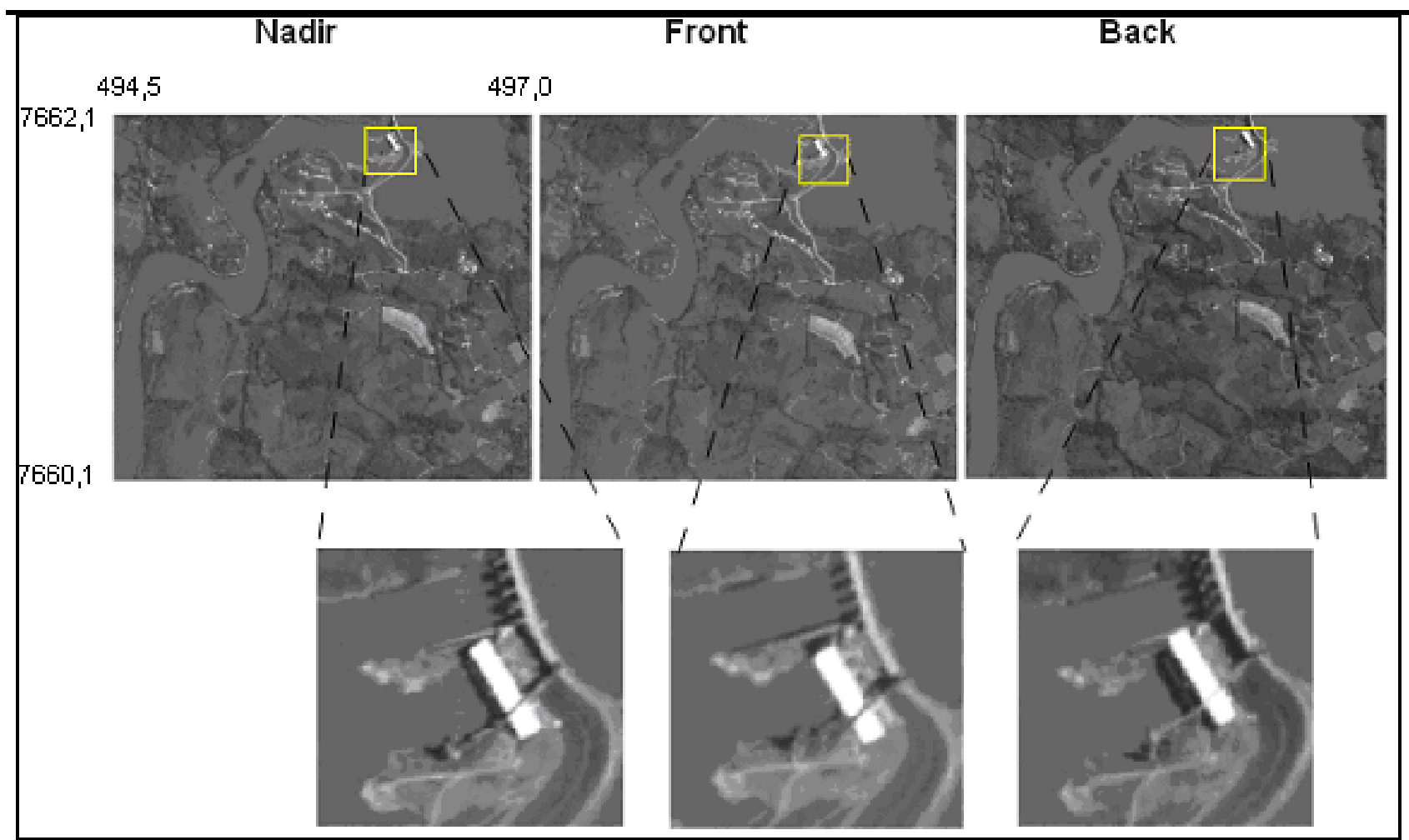

Figura 2 - A mesma cena obtida por diferentes sistemas ópticos, com zoom apresentando diferenças de sombreamento entre elas, devido a inclinação da cena.

Para se obter a visualização estereoscópica, deve-se combinar dois sistemas ópticos, para a mesma cena, com o auxílio de estereoscópio de espelhos. Para isto, as cenas foram exportadas para escala 1:10.000 e posteriormente impressas em papel A4. Em seguida foi gerado um fotoíndice composto por 31 cenas (Figura 3).

É possível adquirir-se diferentes combinações para a visão estereoscópica: Forward + Nadir (FN); Nadir + Backward (NB) ou Forward + Backward (FB). Estas combinações resultam em aspectos visuais distintos: $F N$ apresenta uma face do relevo, enquanto $N B$ a face oposta, porém com um mesmo exagero vertical. Já a combinação $F B$, pelo fato de ambas possuírem inclinação, apresenta maior exagero vertical.

Deve-se ressaltar a necessidade de se encontrar a posição correta para a visualização das cenas impressas, girando-as em noventa graus, até que os topos sejam visualizados nas partes superiores e os fundos de vales nas inferiores. A posição incorreta dos recortes inverte a visão do relevo, o que compromete a visão estereoscópica. 


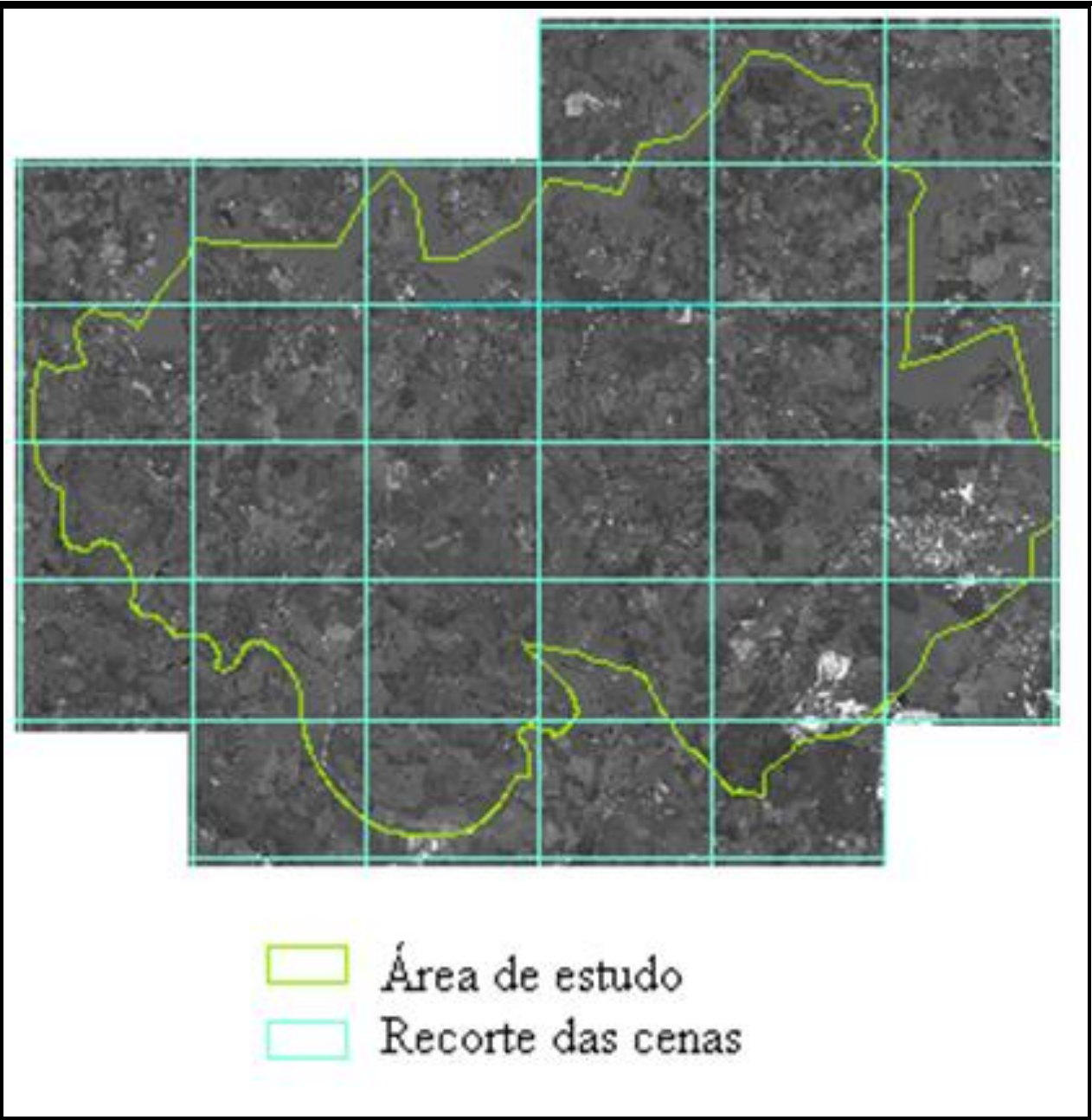

Figura 3 - Fotoíndice contendo as 31 cenas utilizadas na pesquisa

\section{Procedimentos para Análise Geoambiental das Bacias Estudadas}

$\mathrm{Na}$ análise geoambiental das bacias estudadas foram considerados a topografia segundo variáveis morfométricas (classes altimétricas, classes de declividades); morfologia do relevo; unidades pedológicas e o uso do solo. Estas variáveis foram analisadas de maneira integrada pois estão associadas umas às outras, controlando assim, os processos morfodinâmicos. Dentre estes processos cita-se a evolução de processos erosivos lineares e dos movimentos de massa, sendo portanto, imprescindíveis ao planejamento e manejo de bacias hidrográficas.

Produziu-se, desta forma, um conjunto de mapas temáticos tais como: hipsométrico, clinográfico, morfológico, pedológico e uso do solo. Para a geração dos mesmos, utilizaram-se ferramentas de análise espacial, processamento digital e edição de imagens, disponíveis no software ArcMap 10.1 (ESRI, 2013). (Figura 4). 


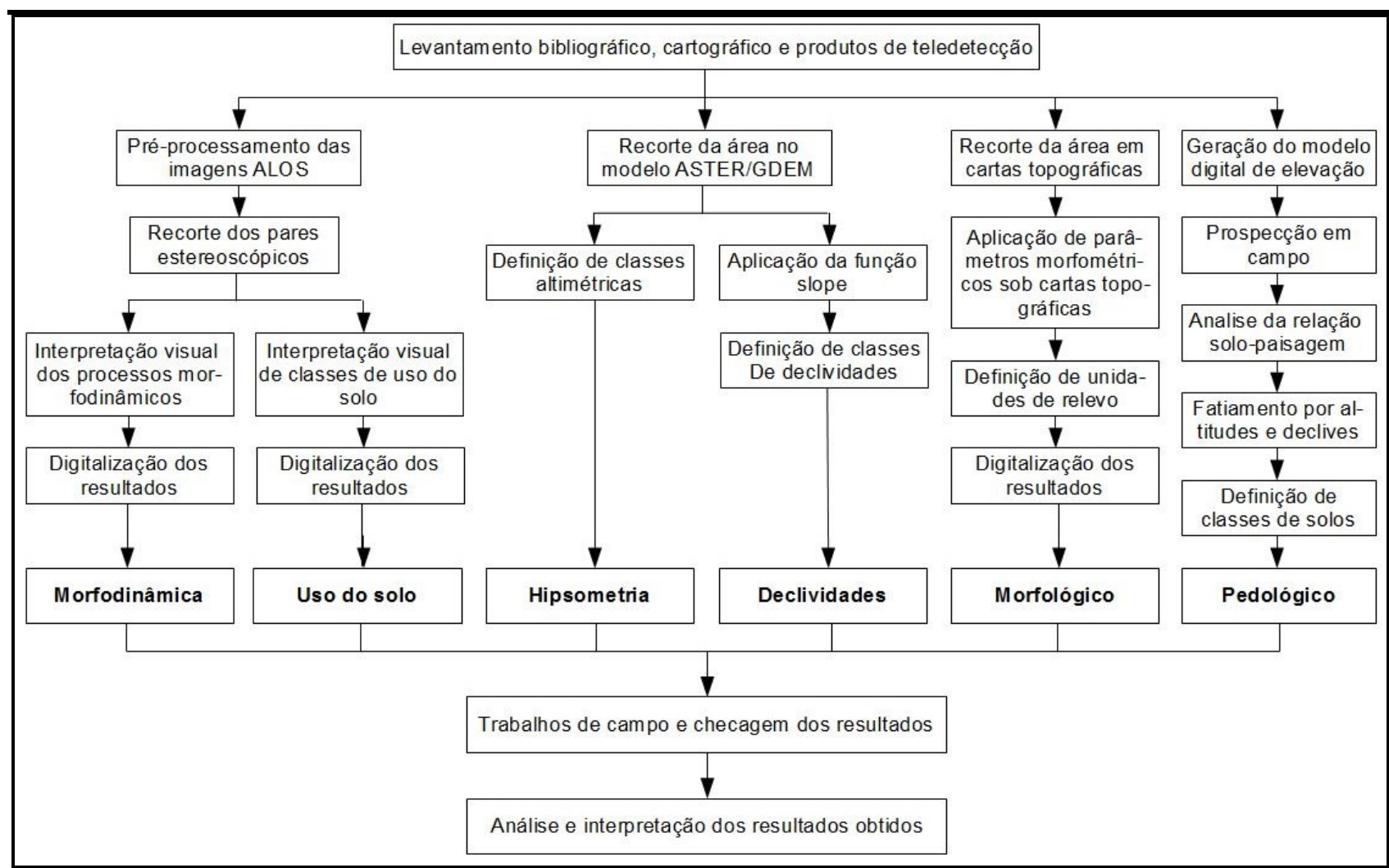

Figura 4 - Fluxograma dos procedimentos metodológicos adotados no trabalho

O mapeamento morfodinâmico da área de estudo (Figura 10) foi realizado por meio de interpretação visual de imagens ALOS/PRISM, utilizando-se a técnica de estereoscopia, e cartas topográficas na escala 1:50.000. Foram mapeadas as seguintes feições: formas de origem fluvial drenagem (rios e córregos); tipos de vales (de fundo plano, em "V" e assimétrico); formas de relevos denudativas (ravinas, anfiteatros de erosão, margens de cursos d'água erodidas); formas de relevo deposicionais (depósitos coluvionares, planícies aluvionares, praias sazonais); formas dos interflúvios (estreitos, arredondados); ação antrópica (mineração, área urbana) e topografia (ponto cotado em metros e curvas de nível).

A simbologia adotada para a representação das feições e das características geomorfológicas baseou-se na metodologia de Verstappen e Zuidan (1975), que associa símbolos das formas à caracterização morfométrica e topográfica.

A identificação das categorias de uso do solo foi realizada por meio da interpretação visual da imagem ALOS/PRISM, por meio de chaves de interpretação e análise estereoscópica. O mapa final foi posteriormente registrado, por funções disponíveis no Georeferencing, do ArcMap 10.1, atribuindo-se pontos de controle de drenagem, obtidos em cartas topográficas.

O mapa hipsométrico foi construído tendo como base o modelo Advanced Spaceborne Thermal Emission and Reflection Radiometer (ASTER) / Global Digital Elevation Model (GDEM). Após o 
recorte da área de estudo, definiram-se classes altimétricas a partir das informações referentes à elevação do terreno em cada pixel - valores Z. Aplicou-se o classificador baseado nas quebras naturais.

Da mesma forma, o mapa clinográfico foi elaborado a partir do modelo ASTER, pela aplicação da função Slope. Obteve-se as declividades (em graus) pela taxa de variação máxima do valor Z em cada pixel do raster, em relação aos vizinhos (ESRI, 2013). A classificação foi também realizada por quebras naturais.

O mapa morfológico foi elaborado com base na interpretação das imagens ALOS/PRISM, adotando-se a metodologia proposta por Pires Neto (1991) que compreende o mapeamento dos tipos de relevo (DEMECK, 1967), também denominado complexo de formas de relevo (SPIRIDONOV, 1980) e unidades genéticas do relevo (VERSTAPPEN e VAN ZUIDAN, 1975).

Esta última unidade taxonômica corresponde a uma associação de formas de relevo, que inclui os sistemas de interflúvios e vales, bem como, seus atributos morfométricos e morfográficos. Com base na fotointerpretação e nos atributos morfométricos e morfográficos extraídos das cartas topográficas de Lavras e Nepomuceno, escala 1:50.000, foram delimitados os seguintes tipos de relevo: Morros com encostas suaves, Morros isolados, Colinas e Planícies Fluviais.

O mapa pedológico foi gerado em escala semidetalhada (1:100.000). Em função da heterogeneidade da área e da compreensão das relações solo-paisagem da região (Curi et al., 1990), as unidades de mapeamento foram caracterizadas a partir de prospecção em campo, segundo os procedimentos normatizados em Santos et al. (2005). O método de prospecção adotado foi o de verificações de campo baseando-se nas correlações solo-paisagem (IBGE, 2007). O material cartográfico utilizado, foi o modelo digital de elevação (MDE) e a declividade, obtido com base nas curvas de nível do IBGE (1973) em escala 1:50.000, que foram interpoladas no software ArcGIS 9.3 e a ferramenta Spatial Analyst para a geração do MDE em mapa do tipo grid (baseado em pixels). As unidades de mapeamento foram delineadas a partir da combinação de diferentes faixas de altitude e de declive, caracterizando porções típicas de ocorrência de classe de solo na área de estudo. Os solos foram classificados de acordo com EMBRAPA (2006).

\section{RESULTADOS E DISCUSSÃO}

As bacias hidrográficas de 2aㅡ, 3a e 4a ordens, foram delimitadas a partir de interflúvios principais com base na metodologia de Strahler (1957). Nas altitudes mais elevadas os vales fluviais das 
bacias são bem encaixados e relacionados às cabeceiras de drenagem. À medida que os cursos d'água se aproximam do rio Grande, à jusante, os vales alternam-se para fundo plano ou assimétricos, desenvolvendo assim, planícies fluviais mais amplas. Nestas planícies observou-se baixo percentual de cobertura vegetal arbórea nas áreas de preservação permanente (APPs), que foram ocupadas por pastagem, culturas anuais e silvicultura.

As altitudes da área variam de 694 a 1041 metros. As menores altitudes encontram-se nos setores agradacionais do rio Grande, nas unidades planícies aluvionares, assim como na confluência entre os córregos formadores das bacias e o rio principal (Figura 5). Já as maiores altitudes, acima dos 1000 metros, estão localizadas em topos e interflúvios arredondados que formam um conjunto de relevos de morros, com amplitudes elevadas e faces de vertentes declivosas.

As declividades variam de 0 a 35 (Figura 6). Os gradientes com intervalos de 0 a 4,70 são observados nas proximidades das planícies do rio Grande e dos córregos pertencentes às bacias, a maioria com hierarquia de 2 a e 3 a ordens. Os maiores declives coincidem com faixas altitudinais até $1040 \mathrm{~m}$, situando-se em vertentes escarpadas de morros e em áreas de cabeceiras de drenagem de canais de 1a e $2 \stackrel{a}{a}$ ordens, com vales predominantemente encaixados. É importante se observar que, no entorno da represa do Funil as declividades elevadas estão associadas a faces de vertentes de colinas e de morros com amplitudes altimétricas entre 20 e 60m, onde o desnível do rio em relação às vertentes possibilitou a instalação da hidrelétrica do Funil.

De maneira geral a área apresenta um conjunto de unidades morfológicas do tipo morros com encostas suaves, colinas e planícies associadas aos principais rios da área (Figura 7). Os morros revelam o domínio de vertentes com rampas longas e declives que variam de $12,4^{\circ}$ a $17,6^{\circ}$, ocorrendo isoladamente declives mais acentuados, entre $17,7^{\circ}$ a $35^{\circ}$. Grande parte das bacias apresenta índice de dissecação forte (bacias dos córregos Pirapum, Paiol, Cafua, Funil, Engenho) caracterizadas por alto grau de entalhamento dos vales, exibindo um conjunto de morros com encostas suaves. Por outro lado, as bacias dos córregos do Pintado, Mutuca, Barreiro, Laranja, Gordura e Palmital, mostram a predominância de relevos de colinas, com vertentes de baixas amplitudes altimétricas e declives que variam de $4,8^{\circ}$ a $12,3^{\circ}$. 


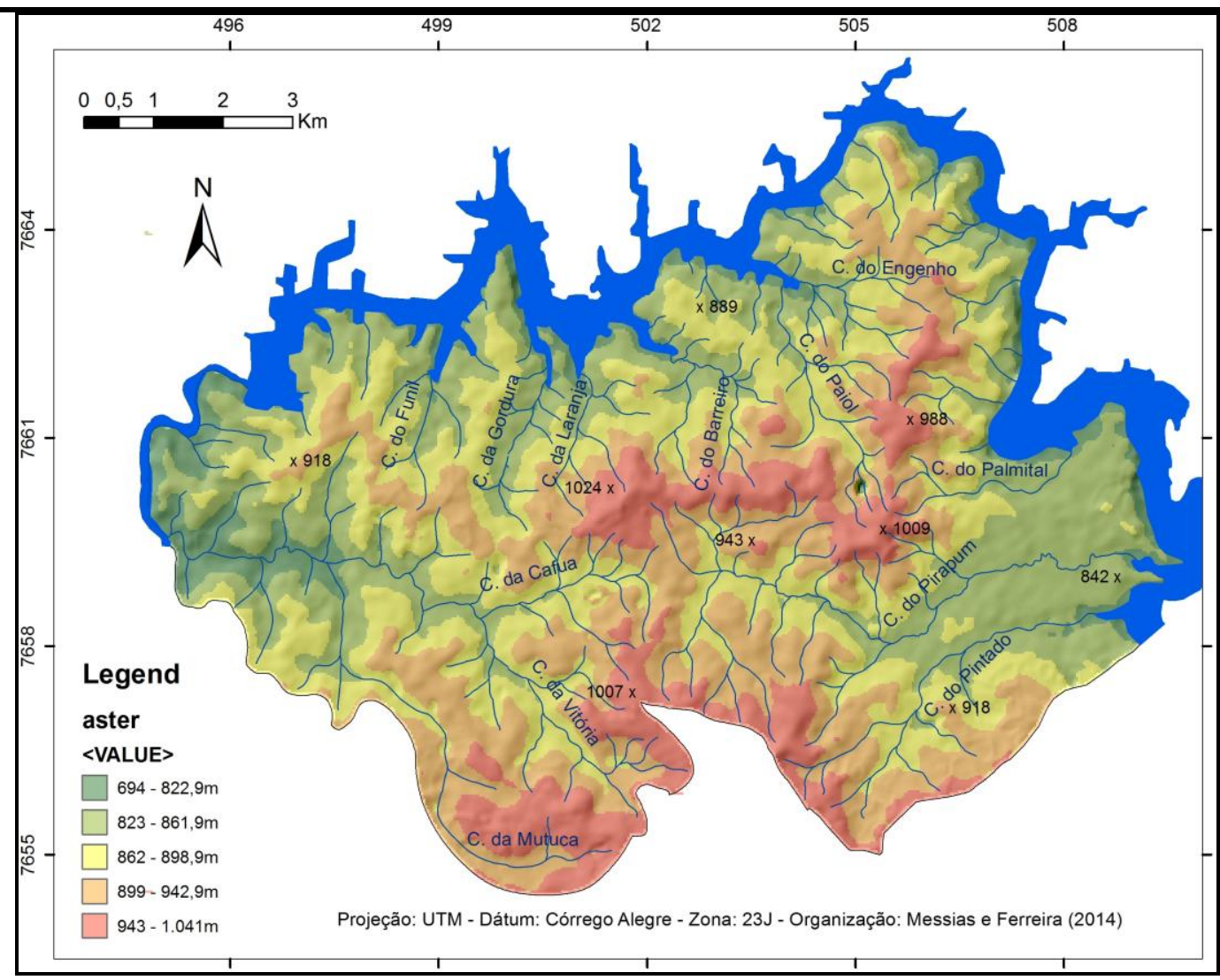

Figura 5 - Mapa hipsométrico da área de estudo.

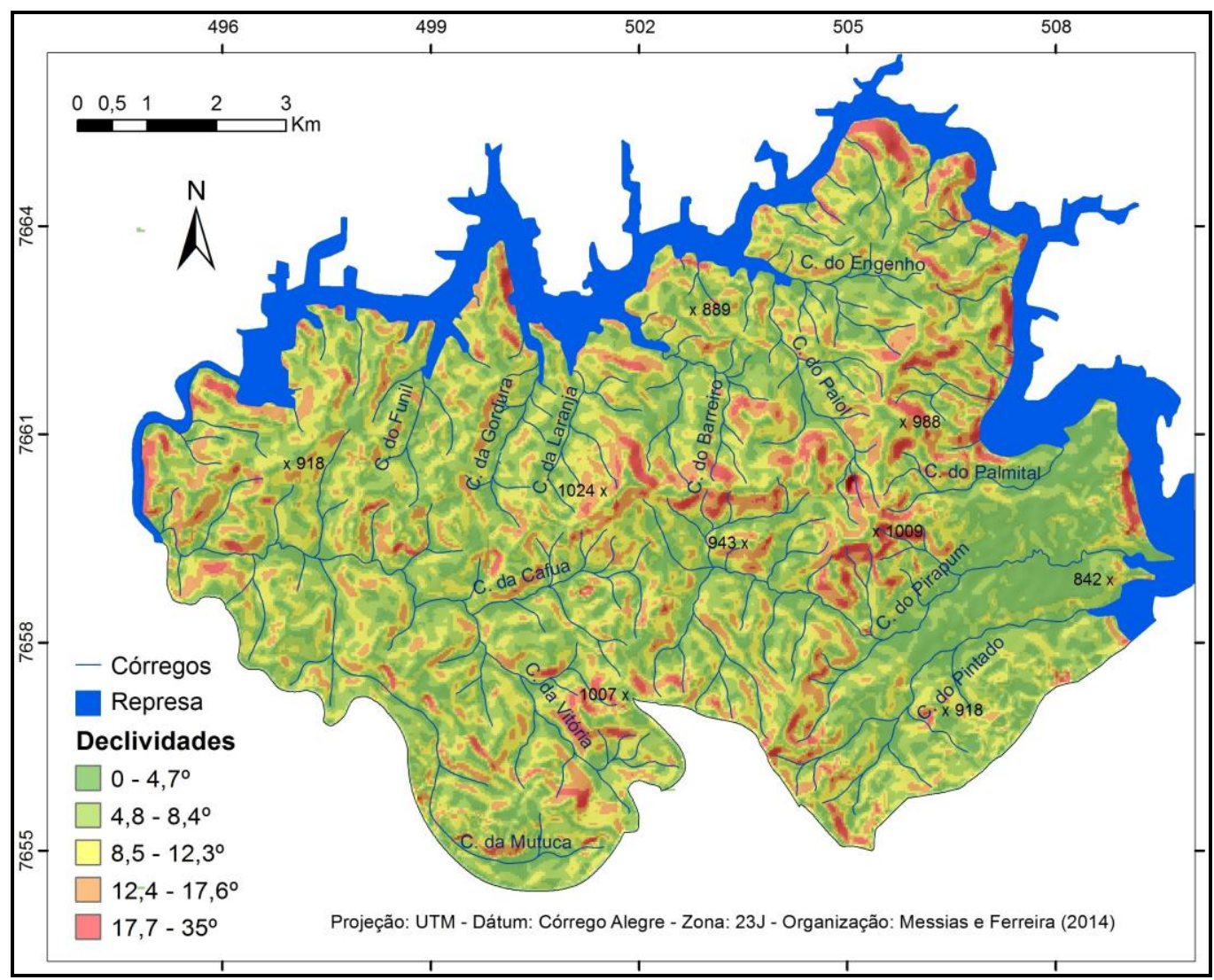

Figura 6 - Mapa clinográfico da área de estudo. 
As unidades de solos presentes na área (Figura 8) são: Latossolos Vermelho-Amarelo, Argissolos, Hidromórficos e associação de Argissolos e Cambissolos. Os Latossolos são predominantes nos relevos de colinas, associados, sobretudo, a vertentes de amplitudes e declividades baixas, entre $4,8^{\circ}$ a $12,3^{\circ}$. Conforme Guerra e Botelho (2012) estes solos são caracterizados por estágio avançado de intemperização e profundidade, comumente porosos e permeáveis. Os Argissolos ocorrem associados a vertentes de relevos de morros com encostas suaves, com declives que variam de 12 a 35․ Os Cambissolos associados aos Argissolos são pouco representativos, incorrendo em topos com vertentes convexas ou retilíneas de faces declivosas (entre 17 e $35^{\circ}$ ), e elevada amplitude. Estes solos apresentam pedogênese pouco desenvolvida, são pouco profundos e, em razão disto, suscetíveis à erosão (GUERRA e BOTELHO, op. cit.).

Os solos Hidromórficos, que se encontram em áreas de planície aluvionar úmida, são formados a partir de sedimentos estratificados ou não, sujeitos a condições de grande umidade e vinculados aos vales de fundo plano, nas bacias dos córregos da Vitória, Pirapum, Pintado, Gordura, Paiol, Mutuca e Barreiro, além de trechos do Rio Grande, não apresentando grande risco à erosão se considerada a topografia plana.

Resultados verificados no mapa de uso e ocupação do solo (Figura 9) mostram que as pastagens, situadas principalmente em Latossolos e Argissolos, ocupam 60,46\% da área estudada. Também com grande representatividade espacial, os cultivos agrícolas ocupam $23,72 \%$ da área e englobam culturas permanentes e anuais. Dentre estes, o café é a principal atividade agrícola da área de estudo.

Barros et al. (2007) analisaram o posicionamento de áreas cafeeiras nos municípios de Aguanil, Boa Esperança, Campo Belo e Cristais, localizados no sudoeste de Minas Gerais, e concluíram que esta cultura está associada a Latossolos e Argissolos bem drenados e profundos. Ademais, a cafeicultura se distribui com maior frequência em baixos declives, especialmente nos inferiores a $8,4^{\circ}$, ocupando vertentes inteiras, desde o fundo de vale ao interflúvio.

As capoeiras e as matas representam em torno de $6 \%$ e $4,3 \%$, respectivamente, acompanhando os cursos d'água, na forma de matas ciliares. Pode-se inferir, pelo mapa da Figura 9, que as margens dos córregos e do reservatório possuem baixa densidade de vegetação, e por isto, vulneráveis à ocorrência de processos erosivos. Consoante à resolução no 303 (de 20 de março de 2002), Art. 3으, inciso l, os córregos ou ribeirões deveriam possuir trinta metros de área de preservação permanente (APP). Já a barragem, pela resolução no 302 (de 20 de março de 2002), Art. $3^{\circ}$, inciso 
I, deveria possuir trinta metros de APP, quando situada em áreas urbanas e cem metros nas áreas rurais (BRASIL, 2002).

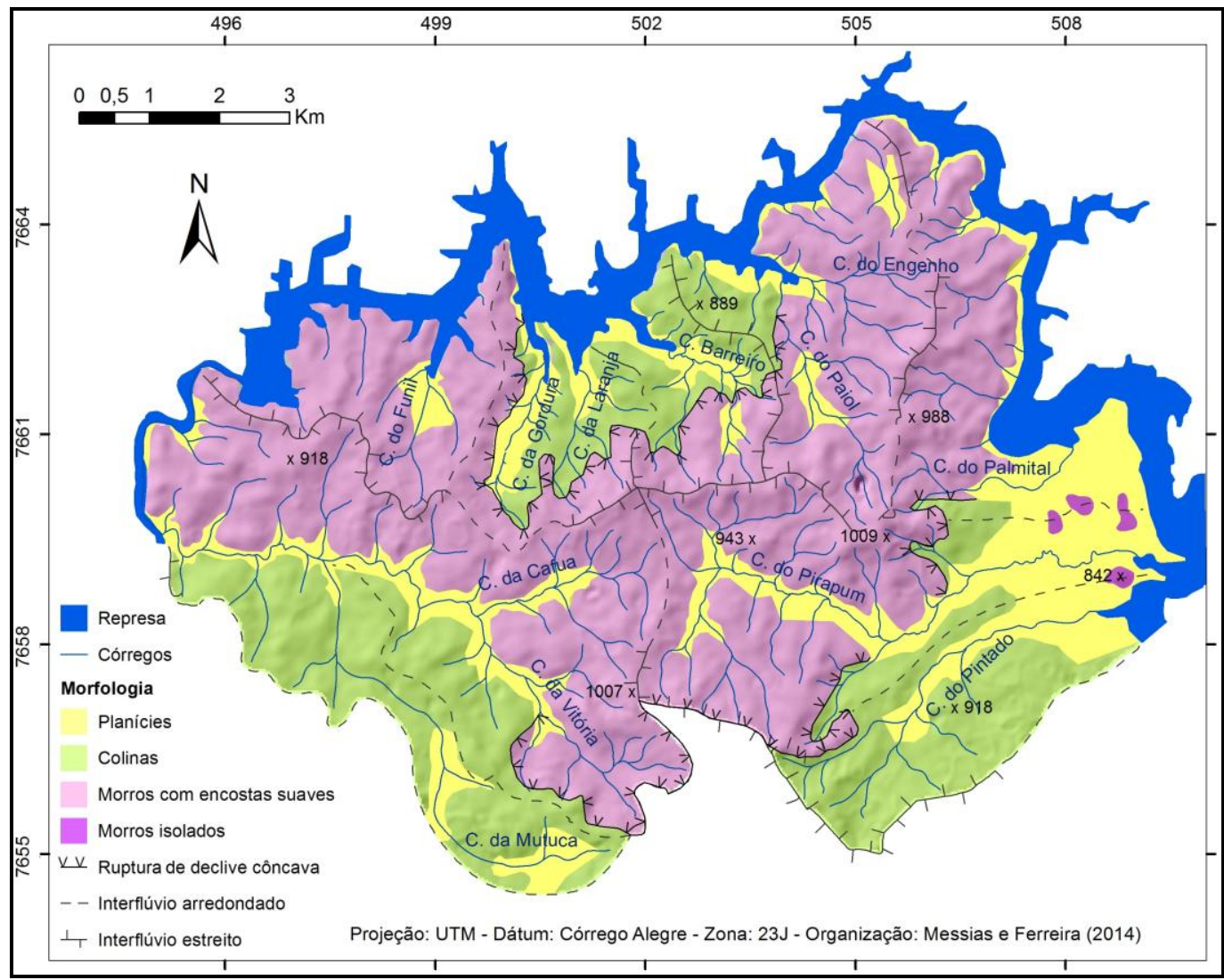

Figura 7 - Mapa morfológico da área de estudo.

Magalhães e Moreira (1998) enfatizam que a atuação de processos morfodinâmicos comumente se vincula a mudanças climáticas e eventos tectônicos, apontados por eles como responsáveis por rupturas no equilíbrio natural das paisagens, culminando na morfogênese e nos efeitos da morfodinâmica. Contudo, a ocupação antrópica na área deve ser destacada, uma vez que os mecanismos de degradação deflagrados por ela se iniciaram em meados do século XVIII, durante o ciclo da mineração. Com a queda da produção do ouro, formaram-se fazendas agropecuárias e, no século XIX, introduziu-se a cultura do café (OLIVEIRA-FILHO e FLUMINHAN-FILHO, 1999). Atualmente encontram-se culturas de milho, banana, fumo e além dessas atividades, o turismo. Conforme descrição dos autores,

[...] na região do alto Rio Grande a cobertura vegetal primitiva foi reduzida a remanescentes esparsos, em sua maioria bastante perturbada pelo fogo, pela pecuária extensiva ou pela retirada seletiva de madeira. As florestas semidecíduas, em particular, foram criticamente reduzidas, uma vez que sua ocorrência coincide com os solos mais férteis e úmidos, e portanto mais visados pela agropecuária (OLIVEIRA-FILHO e FLUMINHAN-FILHO, 1999, p. 2). 


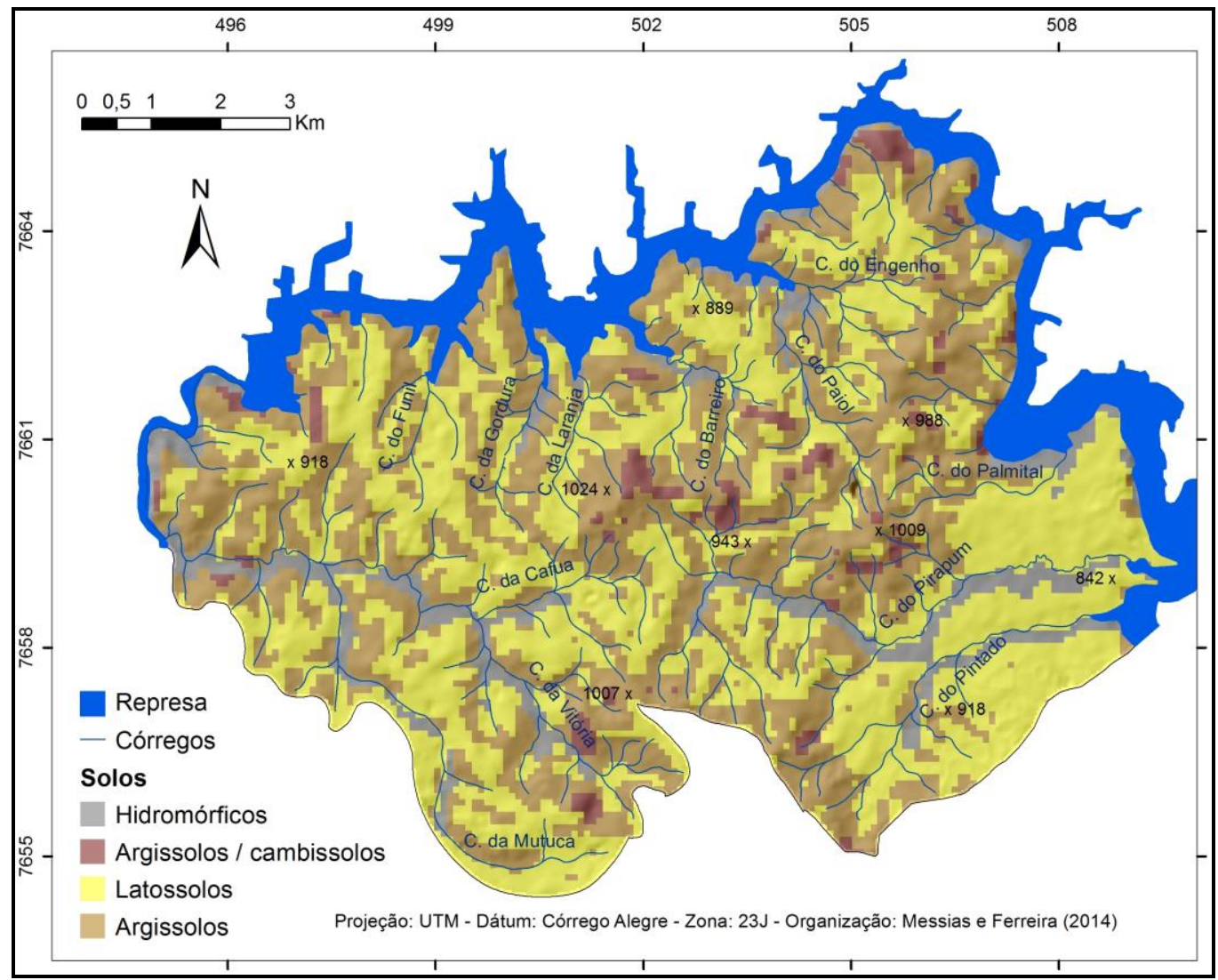

Figura 8 - Mapa pedológico da área de estudo

A análise do mapa morfodinâmico (Figura 10) revela a presença de inúmeros pontos de mineração, sobretudo ao leste da área do estudo, próximo à ljací. Nas bacias dos córregos do Pintado, Pirapum e Palmital, a existência de rochas metacalcário e calcifilito, permitiu a implantação de grandes cavas de extração calcária. Nestes locais as alterações ambientais são visíveis, pois as cavas abertas contribuem para a geração e evolução de processos erosivos lineares como sulcos - que evoluem para ravinas - além dos rejeitos da mineração lançados nos canais das bacias situadas no entorno, constituindo-se em depósitos tecnogênicos úrbicos. Foram mapeadas também as áreas urbanas de ljací, parte de Lavras e a comunidade do Funil, além de usos com menor representatividade, tais como solo exposto e silvicultura. 


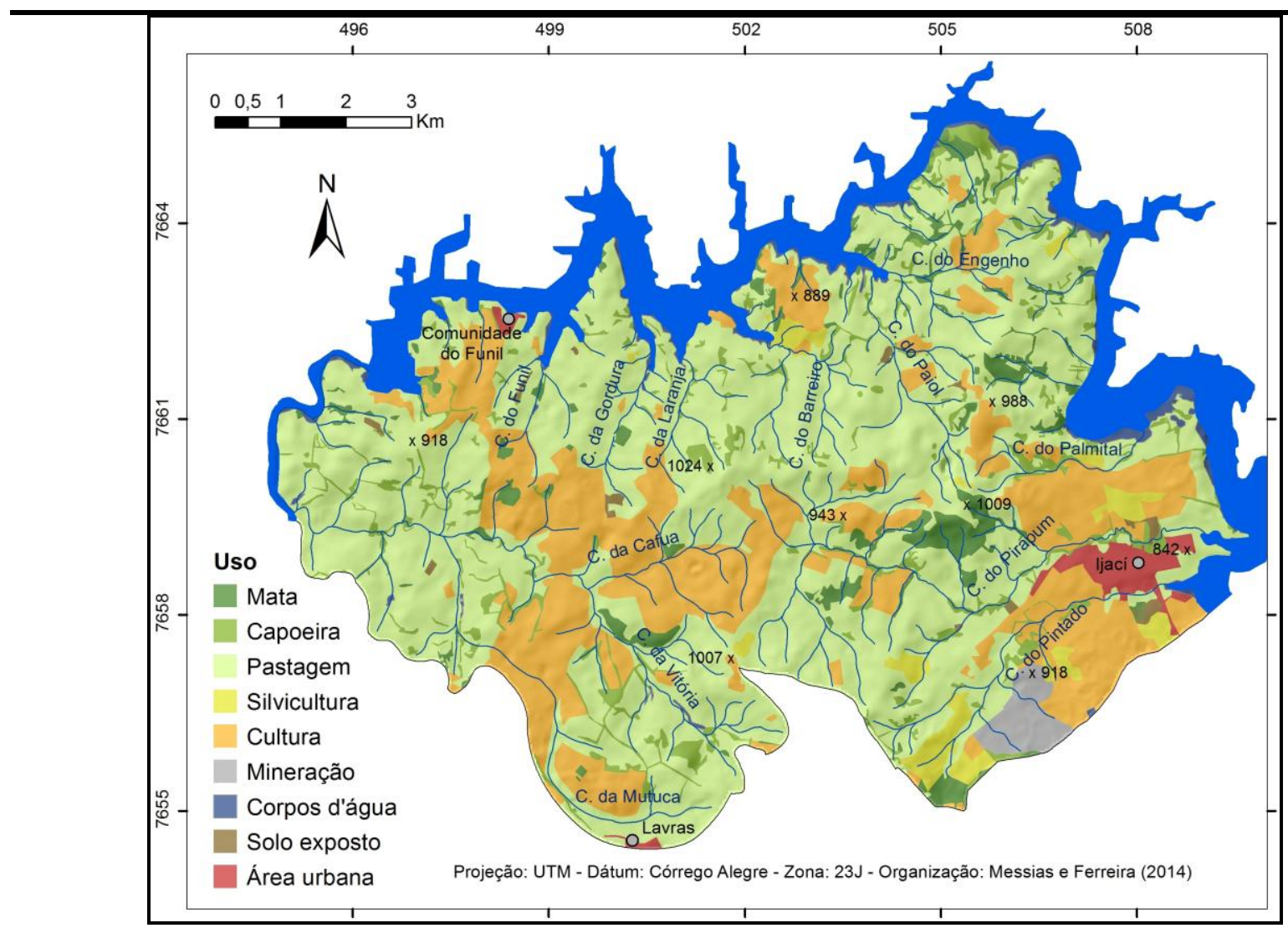

Figura 9 - Mapa de uso do solo da área de estudo

A análise morfodinâmica desenvolvida neste trabalho considerou a frequência de processos de vertentes presentes em grande parte da área, comandados pela água de superfície e denominados de escoamentos, que se incluem na morfogênese pluvial. É o caso das ravinas ou feições erosivas lineares que "[...] iniciadas a uma distância crítica das encostas, resultam do escoamento superficial, que se torna canalizado" (GUERRA, 2012, p. 181). Segundo Bigarella (2007), os ravinamentos ocorrem em quase todas as regiões climáticas, associadas tanto a vertentes suaves, como nas mais íngremes.

Os processos lineares mapeados são do tipo ravinas combinadas a processos elementares como o splash, além de processos mais complexos como o rastejo, que são conduzidos pela ação conjugada entre a gravidade e os escoamentos. Conforme Carson e Kirkby (1972), estes processos são gerados a partir da ruptura de resistência interna dos materiais e as forças externas que impulsionam o deslocamento de um grande volume de material vertente abaixo. Nota-se que os processos de rastejo ocorrem regularmente, associados a vertentes reto-côncavas delimitadas no topo por rupturas de declive convexa, inseridas em relevos de morros com amplitudes elevadas, tendo a pastagem como seu principal uso. 
Foram mapeados trinta e um pontos de ravinamentos, os quais ocorrem preferencialmente em unidades de relevo vinculadas, sobretudo, a morros e colinas com vertentes de perfis convexos e reto-côncavas, ocupadas por pastagens. A análise das ravinas demonstra que as mesmas se localizam predominantemente entre as faixas altimétricas de 862 e 943 metros, acompanhando superfícies das unidades de topos arredondados e estreitos e superfícies situadas em posições da média encosta, cuja principal ocupação é a pastagem rala e o solo exposto. Além disso, sua ocorrência está ligada a fortes gradientes das encostas, que variam de $8,5^{\circ}$ a $35^{\circ}$, em grande parte associadas a Argissolos, que colaboram na intensificação dos sulcos. Entre estas unidades incluemse rupturas e mudanças de declive convexas, que promovem a geração de morfogênese pluvial do tipo splash, seguido por selamento da superfície ocasionando o estabelecimento do escoamento superficial.

Santoro (2012, p. 58) afirma que "o aumento da declividade provoca o aumento do escoamento superficial e, como consequência, cresce também a sua capacidade erosiva [...]". O uso do solo é também de grande importância para a ocorrência destas ravinas na área, devido ao baixo percentual de vegetação densa. Dentre os pontos de ravinamentos, $70,89 \%$ deles situam-se em áreas de pastagem, 19,44\% em áreas de mineração e 9,67\% em cultivos agrícolas. Bigarella (2007) afirmou que as ravinas são feições que usualmente aparecem em áreas desprovidas de vegetação, em terrenos agricultáveis e em locais onde a vegetação foi perturbada, inclusive pelo pisoteio do gado, como ocorre na área estudada.

A partir de evidências de campo e das imagens ALOS/PRISM foram mapeados depósitos de origem gravitacional como os colúvios, formados por materiais remobilizados das encostas mais altas, que aparecem mascarando a topografia dos fundos de vale das bacias, especialmente em locais de declividade alta e ausência de cobertura vegetal. Comumente estes depósitos surgem alojados sobre um manto intemperizado nos sopés das vertentes, bem como, no fundo dos vales e, recobrindo materiais aluvionares encontrados nas bacias dos córregos da Mutuca, da Vitória, do Cafua, do Pintado, do Pirapum, do Engenho, do Palmital e do Funil.

Estes materiais são descritos como areno-argilosos e argilo-arenosos, marrom avermelhados e marrom amarelados, contendo grânulos por vezes centimétricos e decimétricos, subangulosos a subarredondados de quartzo, quartzitos e da rocha subjacente. A caracterização descrita revela que os mesmos podem ser atribuídos a movimentos de massa antigos, que deslocaram mantos de alteração formados em ambiente tropical úmido. Além disto, a textura fina e a presença de grânulos centimétricos e decimétricos, implica em ambientes com profusão de umidade. 
Por outro lado, a presença de ravinas em processo de evolução nas bacias estudadas sugere e explica a consequente formação de depósitos coluvionares recentes e alojados sobre os depósitos antigos. Estes são formados por material argilo-arenoso de textura fina, pouco espesso, indicando deposição recente decorrente de condições climáticas atuais, que promoveram o deslocamento de sedimentos por meio dos escoamentos e movimentos de massa do tipo rastejo, revelando uma instabilidade morfodinâmica atual. Leopold e Völker (2007) afirmam que a gênese do colúvio é influenciada por processos climáticos e pela precipitação local. Ao longo das bacias dos córregos da Vitória, Cafua, Pirapum, Pintado, Gordura, Paiol, Mutuca, Barreiro, e Palmital, as planícies aluvionares formadas por solos hidromórficos, vem sendo entulhadas por materiais argiloarenosos formadores destes depósitos.

Analisando-se as cartas topográficas da área, pôde-se inferir que o segmento do rio Grande escolhido para a instalação e operação do reservatório/barragem do Funil apresentava dinâmica fluvial de águas correntes, degraus ao longo do perfil longitudinal e formação de corredeiras aliado a fluxos turbulentos. Esta característica de fluxo, gerada por elevadas amplitudes altimétricas e forte gradiente do canal fluvial e, pelo grande entalhamento dos vales, favoreceu este tipo de intervenção humana no rio Grande, que rompeu o equilíbrio do perfil longitudinal do rio, alagando as antigas planícies.

De acordo com Cunha (2001), implicações hidrogeomorfológicos decorrentes da construção de barragens geram o rompimento da sequência natural dos rios em três setores: à montante da barragem, no reservatório e à jusante. Os efeitos geomorfológicos observados em campo à jusante da barragem, que mostra maior entalhe no leito do rio Grande, foram: diversos pontos de erosão nas margens; alterações na seção transversal do rio, com migração das áreas de erosão e deposição e, formação de praias sazonais, que permanecem expostas nos períodos de estiagem.

A erosão nas margens do rio Grande é potencializada pelas alterações de descargas referente a operação da barragem, que promove a deposição de materiais, gerando as praias sazonais formadas por materiais finos e seixos arredondados, que surgem principalmente nas margens convexas do rio. Além disso, verificou-se também, a redução altimétrica no nível de base de alguns afluentes formadores das bacias, com retomada erosiva (Figura 10).

Aliados a problemas ambientais destacam-se também os de caráter sócio-econômicos, como deslocamento populacional das áreas inundadas e relocação de famílias para outros terrenos mais elevados, gerando inúmeros conflitos de ordem social. 
Através dos trabalhos de campo, foi possível mapear anfiteatros de erosão que aparecem como reentrâncias topográficas com declividades de $12,4^{\circ}$ a $17,6^{\circ}$, delimitadas por rupturas de declive convexa no topo e faces reto-côncavas em direção ao sopé destas reentrâncias. Estes encontramse ocupados por pastagens já desgastadas pelo pisoteio do gado, o que intensificou o processo de desgaste e a evolução dos anfiteatros, como é o caso das bacias do córrego do Paiol e das bacias menores, deformadas pelas cavas de mineração. No canal de 1a ordem da bacia do córrego do Paiol nota-se um processo de ravinamento inicial expondo a rocha alterada (regolito), ou mesmo, a cobertura pedológica superficial. Além do gado, destaca-se também o entulhamento dos anfiteatros provocado por atividades de mineração situadas à montante, que fornecem maior carga sedimentar aos setores fluviais à jusante.

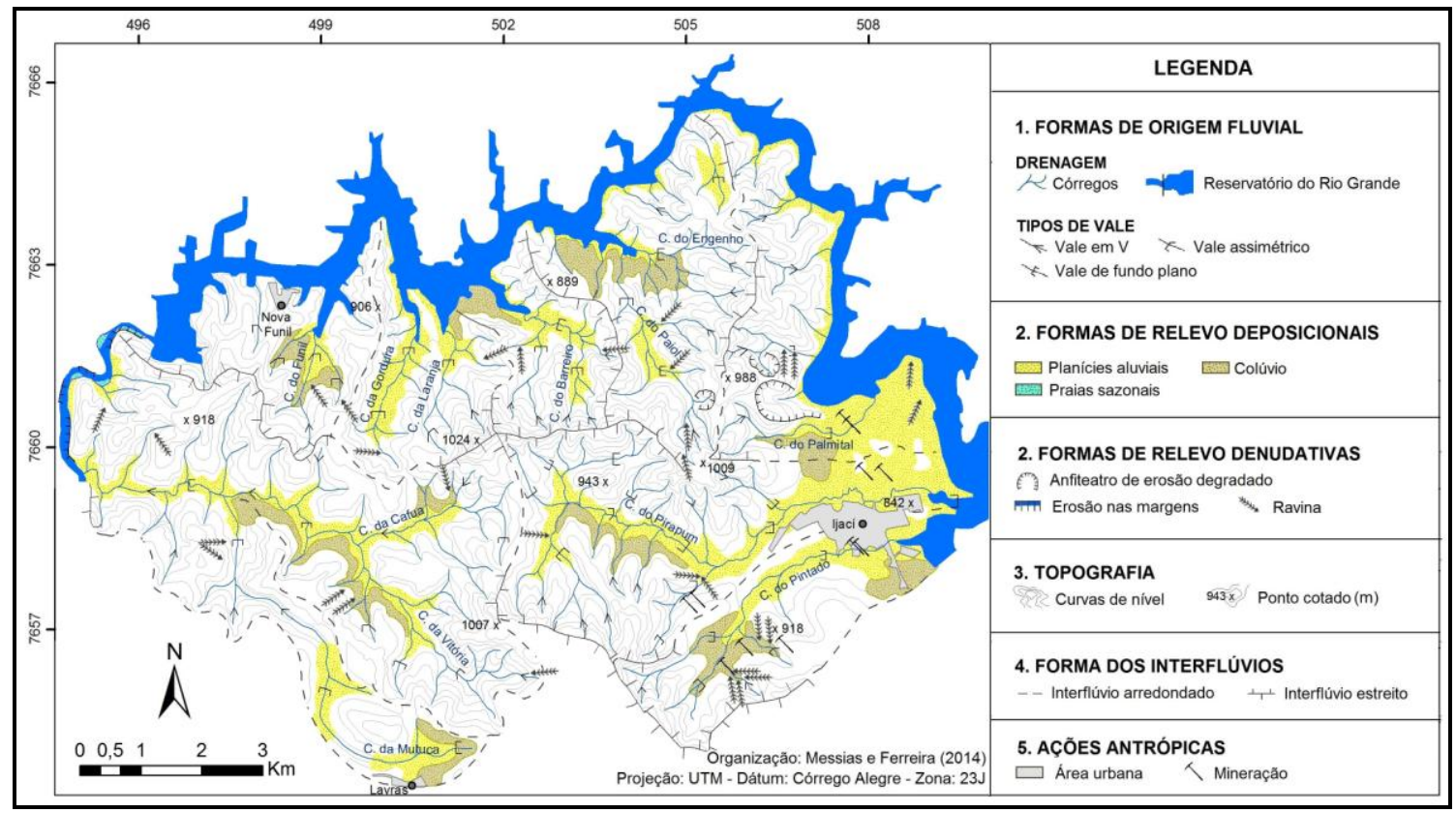

Figura 10 - Mapa morfodinâmico da área de estudo

\section{CONSIDERAÇÕES FINAIS}

Para analisar a complexidade dos fatos geomorfológicos, facilitar sua interpretação, e, sobretudo, fomentar os estudos ambientais, a cartografia geomorfológica desenvolvida neste trabalho foi um processo fundamental pois contribuiu para a representação de elementos relevantes do modelado, e informações espaciais sobre o relevo. O uso da teledetecção espacial e de ferramentas disponíveis em SIG permitiu a obtenção de resultados precisos, por meio da estereoscopia, que facilitou a leitura e representação dos elementos do relevo. 
São escassos na literatura especializada os estudos geomorfológicos de processos em vertentes que empregam as imagens ALOS/PRISM. Ademais, comprovou-se a eficiência de produtos ALOS/PRISM para mapeamentos geomorfológicos em escala de detalhe, favorecidos pela alta resolução espacial e capacidade estereoscópica das imagens.

Para a análise geoambiental foi reunido um conjunto de variáveis que, combinadas, puderam explicar os condicionantes da evolução de processos atuais, sendo portanto, imprescindível aos estudos morfodinâmicos nas bacias estudadas.

Os resultados obtidos nas bacias confirmam a relação direta entre as variáveis naturais mapeadas (hipsometria, declividades, morfologia do relevo e solos), setores de menor altimetria acham-se em unidades de planície, colinas com topos amplos e arredondados vinculados a declividades baixas e à ocorrência de solos com maior espessura, como os Latossolos. Da mesma forma, os setores altimétricos mais elevados que se encontram, sobretudo, em relevos de morros e vertentes de altas amplitudes, possuem declives mais acentuados, desenvolvendo solos rasos, exemplificados por Argissolos e Cambissolos. A morfologia do relevo, controlada pelos tipos de relevo ou unidades morfológicas, agrupa padrões de formas com características de rugosidade topográfica semelhantes, em função da altimetria e morfologia dos topos, do gradiente das vertentes, e da amplitude topográfica.

Grande parte das bacias estão ocupadas por pastagens resultantes da atividade agropecuária tradicional na área, implantadas de maneira irregular nas diferentes formas de relevo, a exemplo inclusive, dos cultivos agrícolas. A vulnerabilidade das bacias, é resultante de alterações na cobertura vegetal representada pelas matas nativas, que produziu espaços com baixa densidade de vegetação, substituída por cultivos agrícolas, pastagem, silvicultura, áreas urbanas, solo exposto e cavas de mineração.

As deficiências de cobertura vegetal e as mudanças de uso do solo, aliadas a morfologia do terreno (declividade, altimetria, amplitude topográfica) e aos solos, desempenharam papel importante no condicionamento dos processos de vertente verificados na área. Estes incluem morfogênese pluvial (splash, ravinas) e movimentos de massa lentos, como o rastejo. As feições de ravinamentos, frequentes na área, são responsáveis pela formação atual de depósitos coluvionares, acomodados sobre colúvios mais antigos, contribuindo para o entulhamento dos vales e a interdigitação destes com os aluviões observados nas bacias dos córregos da Mutuca, da Vitória, do Pintado, do Pirapum, do Engenho, do Barreiro e do Funil. 
As mudanças hidrogeomorfológicas deflagradas pela instalação da barragem do Funil promoveram impactos a jusante da barragem do rio Grande, caracterizadas pela erosão de suas margens e pela formação de praias sazonais, modificando a morfologia da seção do canal. Por outro lado, acredita-se que, na área estudada, os anfiteatros degradados, situados próximo às cavas de mineração do calcário, foram produzidos por esta atividade exploratória sobre cabeceiras em anfiteatros, deformando sua morfologia original ampliando os processos erosivos, facilitando maior deslocamento de materiais para o fundo dos vales.

Pode-se inferir ainda, que eventos climáticos atuais, aliados a ação humana na área, provocam uma instabilidade morfodinâmica confirmada pela remoção e pelo deslocamento de materiais a partir das incisões de ravinamentos e do processo de rastejo. Estas mudanças provocaram um reajuste da rede de drenagem, como também, ativaram movimentos de massa e processos erosivos lineares. Este desequilíbrio está associado não só às características físicas da área, mas também, a fatores antrópicos e sociais.

\section{REFERÊNCIAS BIBLIOGRÁFICAS}

ARGENTO, M. S. F. Mapeamento geomorfológico. In.: GUERRA, A. J. T.; CUNHA, S. B. Geomorfologia: uma atualização de bases e conceitos - 11a ed. Rio de Janeiro: Bertrand do Brasil, p. 365-391, 2012.

BALATKA, B.; SLADEK, J. Problem of the conception of the detailed geomorphological map. In: DEMEK, J. (ed.) Progress made in geomorphological mapping. Brno: IGU Commission on Applied Geomorphology: p.179-192, 1967.

BARROS, M. A.; MOREIRA, M.; A.; RUDORFF, B. F. T. Dados interferométricos para modelagem topográfica e caracterização ambiental do café em escala municipal. In: Sociedade \& Natureza, Uberlândia, v.19, n. 2, p. 33-50, dez. 2007.

BIGARELLA, João José, BECKER, Rosemari D., SANTOS, Gilberto F. dos. Estrutura e origem das paisagens tropicais e subtropicais, vol. 3. Contribuição de Maria Lúcia de Paula Herrmann... [et al.]. - Florianópolis: Ed. da UFSC, 2007. 
BRASIL. Resolução do CONAMA no 302, de 20 de março de 2002. Dispõe sobre os parâmetros, definições e limites de Áreas de Preservação Permanente de reservatórios artificiais e o regime de uso do entorno. Publicado no DOU, de 15/05/2002.

BRASIL. Resolução n 303, de 20 de março de 2002. Dispõe sobre parâmetros, definições e limites de Áreas de Preservação Permanente. Publicada DOU de 13/05/2002.

CARSON, M. A E KIRKBY, M. J. Hillslope Form and Process. University Press, 475p., 1972.

CASTRO, U. N.; NEVES, S. R. A.; SILVA, L. F. T. C., MENDES, S. P.; GUERRA, A. J. TEIXEIRA. Mapeamento de feições erosivas e cicatrizes de escorregamentos por unidades de relevo na subbacia do rio Sana (Macaé-RJ). In.: Revista de Geografia, UFPE, v. especial VIII SINAGEO, n. 3, Set. 2010.

CHAVES, T. A.; CARVAlHO JUNIOR, O. A.; GOMES, R. A. T.; GUIMARÃES, R. F. Análise do uso e cobertura da terra e da fragmentação da paisagem no município de Missal - PR. In.: Boletim de Geografia, Maringá, v. 31, n. 2, p. 69-83, maio-ago. 2013.

CHIGIRA, M.; WU, X.; INOKUCHI, T.; WANG, G. Landslides induced by the 2008 Wenchuan earthquake, Sichuan, China. In.: Geomorphology, v. 118, p. 225-238, 2010.

CHOLLEY, A. Morphologie Structuralle et Morphologie Climatique. Annales de Géographie, LIX, n. 317, nov.-dec., Paris, 1950.

CUNHA, C. M. L.; MENDES, I. A.; SANCHEZ, M. C. Técnicas de elaboração, possibilidades e restrições de cartas morfométricas na gestão ambiental. In.: Revista de Geografia, Rio Claro, v. 28, n. 3, p. 415-429, set./dez. 2003.

CUNHA, S. B. Geomorfologia Fluvial. In: GUERRA, A.J.T.; CUNHA, S.B. (orgs.). Geomorfologia uma Atualização de Bases e Conceitos. 4. ed. Rio de Janeiro: Bertrand Brasil, p. 211-252, 2001.

CURI, N.; LIMA, J. M. de; ANDRADE, H.; GUALBERTO, V. Geomorfologia, Geologia, Química e Mineralogia dos principais solos da região de Lavras (MG). In: Ciência e Prática, Lavras, v.14, p.297-307, 1990.

DANTAS, A. A. A.; CARVALHO, L. G.; FERREIRA, E. Classificação e tendências climáticas em Lavras, MG. In.: Ciênc. Agrotec., Lavras, v. 31, n. 6, p. 1862-1866, nov./dez., 2007. 
DEMEK, J. Generalization of geomorphological maps. In: DEMEK, J. (ed.) Progress made in geomorphological mapping. Brno, IGU Commission on Applied Geomorphology: p.36-72, 1967.

EMBRAPA. Sistema Brasileiro de Classificação de Solos - 2. ed. Rio de Janeiro: EMBRAPA, 306 p., 2006.

ESRI. Help. ArcGIS Desktop 10.1, 2013.

GUERRA, A. J. T. Processos erosivos nas encostas. In.: GUERRA, A. J. T.; CUNHA, S. B. Geomorfologia: uma atualização de bases e conceitos - 11a ed. Rio de Janeiro: Bertrand do Brasil, p. 149-209, 2012.

GUERRA, A. J. T.; BOTELHO, R. G. M. Erosão dos solos. In.: CUNHA, S. B.; GUERRA, A. J. T. (orgs.). Geomorfologia do Brasil - 8ae ed. Rio de Janeiro: Bertrand do Brasil, p. 181-227, 2012.

GUSTAVSSON, M.; SEIJMONSBERGEN, A. C.; KOLSTRUP, E. Structure and contents of a new geomorphological GIS database linked to a geomorphological map - With an example from Liden, Central Sweden. In.: Geomorphology, v. 95, p. 335-349, 2008.

IBGE. Carta do Brasil. Rio de Janeiro, 1 mapa. Escala: 1:50000, 1973.

IBGE. Manual Técnico de Pedologia (2ª ed.). Rio de Janeiro, RJ. 2007. 316 p.

ILWIS. Integrated land and water information system. 52North Exploring horizons, http://52 north.org., 2007.

JOLY, F. Point de vue sur la géomorphologie. Ann. de Géographie, 13, 1977.

KLIMASZEWSKI, M. Problems of geomorphological mapping. Varsóvia, Academia Polonesa de Ciências. (Estudo Geográfico. 46), 1963.

LEOPOLD, M., VÖLKER, J. Colluvium: definition, differentiation, and possible suitability for reconstructing Holocene climate data. In.: Quaternary International, v. 162-163: 133-140, 2007.

LOUREIRO, H. A. S.; FERREIRA, S. M. O papel das geotecnologias no estudo das feições erosivas e de movimentos de massa. In.: GUERRA, A. F. T.; JORGE, M. C. O. (Orgs). Processos erosivos e recuperação de áreas degradadas. São Paulo: Oficina de Textos, pag. 95-125, 2013. 
MAGALHÃES, Jr. A.; MOREIRA, P. de F. Eventos de "desequilíbrio morfodinâmico" na evolução geomorfológica de Minas Gerais - o caso de Teófilo Otoni/Caraí - região nordeste do estado. Geonomos, 6 (2): 23-32, Belo Horizonte, 1998.

MARUJO, M. F. Ensaio de Cartografia Morfológica Detalhada de Um Setor das Escarpas do Planalto de Campos do Jordão, Serra da Mantiqueira, SP. Dissertação de Mestrado (Departamento de Geografia), FFLCH, USP, 180 p., 1994.

MODENESI, M.C. Depósitos de vertente e evolução quaternária do Planalto do Itatiaia. Revista IG, São Paulo, 13(1), 31-46, jan. jun., 1992.

NIKOLAKOPOULOS, K. G.; GIOTI, E. Accuracy control of ALOS DSM. In.: $30^{\text {th }}$ Remote Sensing for Science, Education and Natural and Cultural Heritage, Rainer Reuter Editor), EARSeL, Paris, France, 2010.

OLIVEIRA - FILHO, A. T.; FLUMINHAN- FILHO, M. Ecologia da vegetação do parque florestal Quedas do Rio Bonito. In.: Revista Cerne, Lavras: UFLA, 1999.

OLIVEIRA FILHO, A.T., VILELA, E.A., GAVILANES, M.L. \& CARVALHO, D.A. Comparison of the woody flora and soils of six areas of montane semideciduous forest in Southern Minas Gerais, Brazil. In.: Edinburgh Journal of Botany, Edinburgh, v. 51, n. 3, p. 355-389, 1994.

PIRES NETO, A. G. As abordagens sintético-histórica e analítico-dinâmica: uma proposição metodológica para a geomorfologia. Tese de Doutoramento, Departamento de Geografia-USP, $302 p ., 1991$.

RODRIGUES, S.C. Análise empírico-experimental da fragilidade do relevo-solo no cristalino do Planalto Atlântico: sub-bacia do reservatório Billings. Tese de Doutorado, FFLCH-USP, São Paulo, 267p, 1998.

ROSS, J. L. S. O registro cartográfico dos fatos geomórficos e a questão da taxonomia do relevo. In: Revista do Departamento de Geografia, FFLCH-USP,n. 6. São Paulo, 1992.

SANTORO, J. Erosão continental. In.: TOMINAGA, L.K; SANTORO, J.; AMARAL, R. Do (Orgs). Destrastres Naturais: conhecer e previnir - 2ª ed. São Paulo: Instituto Geológico, 2012. 
SANTOS, R. D.; LEMOS, R. C.; SANTOS, H. G.; KER, J. C.; ANJOS, L. H. C. Manual de descrição e coleta de solo no campo. 5ạ ed. (revista e ampliada). Viçosa, Sociedade Brasileira de Ciência do Solo, 100p., 2005.

SILVA, J. X. Geomorfologia e Geoprocessamento. In.: GUERRA, A. J. T.; CUNHA, S. B. Geomorfologia: uma atualização de bases e conceitos - 11a ed. Rio de Janeiro: Bertrand do Brasil, p. 393-414, 2012.

SOUZA, L. H. F.; FERREIRA, I. L.; RODRIGUES, S. C. Cartografia digital aplicada ao mapeamento geomorfológico. In.: Sociedade e Natureza, v. 16, n. 30, Uberlândia, p. 133-144, jun. 2004.

SOUZA, L. H. Representação Gráfica de Feições Lineares do Relevo: Proposta de Aplicação de Simbologia Linear Digital na Cartografia Geomorfológica. Dissertação de Mestrado. Instituto de Geografia da UFU, 2006.

SPIRIDONOV, A I. Princípios de la metodologia de las investigaciones de campo y el mapeo geomorfologico. Havana, Univ. de Havana, 657p., 1980.

STRAHLER, A.N. Quantitative analysis of watershed geomorphology. In.: Transactions: American Geophysical Union, v. 38, New Halen, p. 913-920, dez. 1957.

TRICART, J. Principes et méthodes de la géomorphologie. Paris: Masson, 1965.

VERSTAPPEN, H. Th. Applied gemorphology: Geomorphological surveys for environmental development. Netherlands: Elsevier Science Publish, 437 p., 1983.

VERSTAPPEN, H. Th.; ZUIDAM, R. A. van. ITC System of Geomorphological Survey. Dutchland: Enschede Textbook ITC, 49 p., 1975.

Artigo submetido em: 29/06/2014

Artigo aceito em: 19/09/2014 